\title{
The Loss of Cellular Junctions in Epithelial Lung Cells Induced by Cigarette Smoke Is Attenuated by Corilagin
}

\author{
Ximena M. Muresan, ${ }^{1}$ Franco Cervellati, ${ }^{1}$ Claudia Sticozzi, ${ }^{1}$ \\ Giuseppe Belmonte, ${ }^{1}$ Chung Hin Chui, ${ }^{2}$ Ilaria Lampronti, ${ }^{3}$ Monica Borgatti, ${ }^{1}$ \\ Roberto Gambari, ${ }^{1}$ and Giuseppe Valacchi ${ }^{1}$
}

${ }^{1}$ Department of Life Sciences and Biotechnology, University of Ferrara, 44121 Ferrara, Italy

${ }^{2}$ Clinical Division, School of Chinese Medicine, Hong Kong Baptist University, Kowloon Tong, Hong Kong

${ }^{3}$ Biotechnology Center, University of Ferrara, 44121 Ferrara, Italy

Correspondence should be addressed to Giuseppe Valacchi; giuseppe.valacchi@unife.it

Received 25 November 2014; Revised 2 January 2015; Accepted 21 January 2015

Academic Editor: Neelam Khaper

Copyright (C) 2015 Ximena M. Muresan et al. This is an open access article distributed under the Creative Commons Attribution License, which permits unrestricted use, distribution, and reproduction in any medium, provided the original work is properly cited.

\begin{abstract}
Cigarette smoke (CS) contains over 4700 compounds, many of which can affect cellular redox balance through free radicals production or through the modulation of antioxidant enzymes. The respiratory tract is one of the organs directly exposed to CS and it is known that CS can damage the integrity of lung epithelium by affecting cell junctions and increasing epithelium permeability. In this study, we have used a human lung epithelial cell line, Calu-3, to evaluate the effect of CS on lung epithelial cell junctions levels, with special focus on the expression of two proteins involved in intercellular communication: connexins (Cx) 40 and 43 . CS exposure increased $\mathrm{Cx} 40$ gene expression but not of $\mathrm{Cx} 43$. CS also induced NF $\kappa \mathrm{B}$ activation and the formation of $4 \mathrm{HNE}-\mathrm{Cxs}$ adducts. Since corilagin, a natural polyphenol, is able to inhibit NF $\kappa$ B activation, we have determined whether corilagin could counteract the effect of CS on Cxs expression. Corilagin was able to diminish CS induced Cx40 gene expression, $4 \mathrm{HNE}-\mathrm{Cx} 40$ adducts formation, and $\mathrm{NF} \kappa \mathrm{B}$ activation. The results of this study demonstrated that CS induced the loss of cellular junctions in lung epithelium, possibly as a consequence of $\mathrm{Cx}-4 \mathrm{HNE}$ adducts formation, and corilagin seems to be able to abolish these CS induced alterations.
\end{abstract}

\section{Introduction}

Cigarette smoke (CS) is a heterogeneous mixture formed by a gaseous phase and solid particles, and it contains more than 4700 compounds, including carcinogen and oxidant substances $[1,2]$. Due to its ability to induce cellular oxidative stress, CS causes noxious effects in a large part of human organs, such as cardiovascular system [3], cutaneous tissues [4], retina [5], and of course lung tissues. The ability of CS to induce oxidative stress has been associated with cellular damage such as DNA mutations [6], lipid peroxidation with formation of reactive aldehydes [7], and proteins oxidation [8]. In addition, it is documented that CS is able to promote inflammatory responses in cells, via TNF- $\alpha$ and NF $\kappa$ B signaling pathway [9].
The main target of CS is obviously the respiratory tract characterized by a pseudostratified epithelium, which acts as a barrier protecting the organism from environmental antigens. Respiratory epithelial cells are bound together by different cellular junctions, as described in Heijink et al. [10]. Gap junctions, in particular, are membrane channels formed by the union of two hemichannels belonging to adjacent cells; these hemichannels are also known as connexons; each of them is composed of six connexins that are four-pass transmembrane proteins [11]. Gap junctions have multiple functions, by allowing the direct passage of ions, second messengers, and metabolites among cells. Therefore, gap junctions allow an essential communication that maintains normal functions of tissues and organs [12]. These communications are important in all physiological cellular processes, 
such as cell growth, cell development, cell differentiation, and cell death, and its absence leads to changes in the cellular homeostasis [13]. In addition, connexins are known to affect cell migration and adhesion [14-16].

In the last few decades, many studies have shown that polyphenols and oxidant scavengers can contrast CS induced oxidative stress [17-20]. Corilagin is a polyphenol, member of the tannin family extracted from different plants like Dimocarpus longan [21] and Geranium thunbergii [22]. This natural compound seems to have beneficial effects in several cardiovascular disorders, hypertension, thrombosis, or atherosclerosis [23], but it is also known for its antiproliferative and antitumor effects [24]. Zhao et al. have demonstrated the anti-inflammatory properties of corilagin. Their study shows that corilagin is able to block $\mathrm{NF} \kappa \mathrm{B}$ activation and its nuclear translocation, demonstrating anti-inflammatory characteristic. In addition, it has been shown that corilagin decreases the production of proinflammatory cytokines like TNF- $\alpha$, IL-1 $\beta$, IL-6, iNOS, and COX-2 [25]. Furthermore, some studies have evidenced the ability of corilagin to inhibit IL- 8 production by blocking TNF- $\alpha$ induced NF $\kappa$ B nuclear translocation [26]. It has been also demonstrated that corilagin is hepatoprotective as it acts like radical scavenger for superoxide anion and peroxyl radicals. In addition corilagin inhibits ROS production from leukocytes as well as free radicals formation and lipid peroxidation in mitochondria [27].

In our study we evaluated the damaging effects of CS on lung epithelial cells; in particular we investigated CSmodulation of gap junctions and connexin expression and we also determined whether corilagin could counteract the noxious effect of CS. For our purpose, we have used Calu-3 cell line grown in air-liquid interface, which has been reported to be a good model to study biological agents on human airway epithelial cells functions and structures. Indeed this model has been extensively used for lung pathophysiology and therapeutics studies and it exhibits many characteristics of the primary airway cell cultures thanks to its ability to form stable cell-to-cell junctions [28].

\section{Materials and Methods}

2.1. Cell Culture and Treatment. Calu-3 cells cultured in $75 \mathrm{~cm}^{2}$ plastic flasks (BD Falcon, USA) were grown in Dulbecco's modified Eagle's medium (Lonza, Milan, Italy) supplemented with $10 \%$ fetal bovine serum (EuroClone, Milan, Italy), $2 \mathrm{mM}$ L-glutamine (Lonza, Milan, Italy), and antibiotics $(100 \mathrm{UI} / \mathrm{mL}$ penicillin and $100 \mu \mathrm{g} / \mathrm{mL}$ streptomycin) (Lonza, Milan, Italy). They were maintained at $37^{\circ} \mathrm{C}$ in a humidified $5 \% \mathrm{CO}_{2}$ atmosphere. Upon reaching $90 \%$ confluence, cells were harvested using $0,02 \%$ trypsin/EDTA (Lonza, Milan, Italy). After trypsinisation, Calu-3 cells were seeded at a density of $1 \times 10^{6}$ cells $/ \mathrm{mL}$ onto $0.4 \mu \mathrm{m}$ pore size, $4.15 \mathrm{~cm}^{2}$ surface area polyethylene terephthalate Transwell cell culture inserts (BD Falcon, USA), placed in 6-well cell culture plates (BD Falcon, USA). When the cells reached $90 \%$ of confluence and were pretreated with corilagin $10 \mu \mathrm{M}$ for $24 \mathrm{hr}$, then the culture media were changed and the cells were exposed to CS.
Corilagin was a gift by the China National Institute for the Control of Pharmaceutical and Biological Products. The powder was dissolved in ethanol and the $10 \mu \mathrm{M}$ solution was added to the cells (final ethanol concentration $0.1 \%$ ).

2.2. CS Exposure. Cells were exposed to CS for $50 \mathrm{~min}$ in fresh serum-free media (as previously described [29]) while control cells were exposed to filtered air $(50 \mathrm{~min})$. CS was generated by burning one research cigarette ( $12 \mathrm{mg}$ tar, $1.1 \mathrm{mg}$ nicotine) using a vacuum pump to draw air through the burning cigarette and leading the smoke stream over the cell culture as described previously [29]. After the exposure (air or CS), fresh media supplemented with $10 \%$ FBS were added to the cells.

2.3. Cytotoxicity Determination. After CS exposure, culture media were collected at different time points $(50 \mathrm{~min}, 6 \mathrm{hr}$, $12 \mathrm{hr}$, and $24 \mathrm{hr}$ ). Cytotoxicity was determined by LDH release in the media, measured by enzymatic assay; in the first step $\mathrm{NAD}^{+}$is reduced to $\mathrm{NADH} / \mathrm{H}^{+}$by the $\mathrm{LDH}$-catalyzed conversion of lactate to pyruvate; in the second step the catalyst (diaphorase) transfers $\mathrm{H} / \mathrm{H}^{+}$from $\mathrm{NADH} / \mathrm{H}^{+}$to tetrazolium salt which is reduced to formazan. The amount of $\mathrm{LDH}$ in the supernatant was determined and calculated according to kit instructions (EuroClone Milan, Italy). All tests were performed in triplicate and assays were repeated three times independently.

2.4. Protein Extraction. At each time point cells were washed with ice-cold PBS and lysed in ice-cold lysis buffer

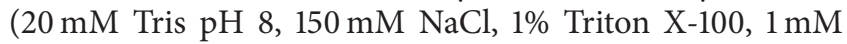
sodium orthovanadate, $1 \mu \mathrm{g} / \mathrm{mL}$ leupeptin, $1 \mu \mathrm{g} / \mathrm{mL}$ aprotinin, $1 \mu \mathrm{g} / \mathrm{mL}$ pepstatin, $10 \mu \mathrm{g} / \mathrm{mL}$ PMSF, and $5 \mathrm{mM} \beta$ glycerophosphate) (Sigma, Milan, Italy). After centrifugation $\left(13,500 \mathrm{rpm}, 15 \mathrm{~min}\right.$ at $\left.4^{\circ} \mathrm{C}\right)$, the supernatants were collected. Proteins concentration was determined by the method of Bradford (BioRad, Milan, Italy).

2.5. Western Blot Analysis. Sixty $\mu$ g boiled protein was loaded onto $10 \%$ sodium dodecyl sulphate-polyacrylamide electrophoresis gels and separated by molecular size. Gels were electroblotted onto nitrocellulose membranes and then were blocked for $1 \mathrm{hr}$ in Tris-buffered saline, $\mathrm{pH} 7.5$, containing $0.5 \%$ Tween 20 and 3\% milk. Membranes were incubated overnight at $4^{\circ} \mathrm{C}$ with the appropriate primary antibodies: Cx40 (Santa Cruz Biotechnology Inc., USA), Cx43 (Santa Cruz Biotechnology Inc., USA), 4HNE (Chemicon, USA), and $\beta$-actin (Cell Signalling, Celbio, Milan, Italy). The membranes were then incubated with horseradish peroxidaseconjugated secondary antibody for $1 \mathrm{hr}$, and the bound antibodies were detected by chemiluminescence (BioRad, Milan, Italy). $\beta$-actin was used as loading control. Images of the bands were digitized and the densitometry analysis was performed using ImageJ software.

2.6. Electrophoretic Mobility Shift Assay (EMSA). Electrophoretic Mobility Shift Assay (EMSA) was performed as previously described [30, 31]. Briefly, double-stranded synthetic oligodeoxynucleotides mimicking two functional 
$\mathrm{NF} \kappa \mathrm{B}$ binding sites displaying different sequence (A, sense: $5^{\prime}$-GTT CTG GGA TTT CCC CCG AT- $3^{\prime}$; B, sense: $5^{\prime}$ CAG CAG GAA CGT CCC AGA GAA-3') [32] have been employed. Oligodeoxynucleotides were labeled with $\gamma^{32}$-PATP using 10 units of T4-polynucleotide-kinase (KinaseMAX, Ambion) in $500 \mathrm{mM}$ Tris- $\mathrm{HCl}$, $\mathrm{pH} 7.6,100 \mathrm{mM} \mathrm{MgCl}_{2}$, $50 \mathrm{mM}$ DTT, $1 \mathrm{mM}$ spermidine, and $1 \mathrm{mM}$ EDTA in the presence of $50 \mathrm{mCi} \gamma^{32}$-P-ATP in a volume of $20 \mu \mathrm{L}$ for 60 minutes at $37^{\circ} \mathrm{C}$. Reaction was brought to $150 \mathrm{mM} \mathrm{NaCl}$ and $150 \mathrm{ng}$ complementary oligodeoxynucleotide was added. Reaction temperature was increased to $100^{\circ} \mathrm{C}$ for 5 minutes and left diminishing to room temperature overnight. Binding reactions were set up as described elsewhere [30] in a total volume of $20 \mu \mathrm{L}$ containing buffer TF plus 5\% glycerol, $1 \mathrm{mM}$ dithiothreitol, $5 \mathrm{ng}$ of human $\mathrm{NF} \kappa \mathrm{B}$ p50 protein, and different concentrations of corilagin. After incubation of $20 \mathrm{~min}$ at room temperature, $0.25 \mathrm{ng}$ of ${ }^{32} \mathrm{P}$-labeled oligonucleotides was added to the samples for further $20 \mathrm{~min}$ at room temperature and then they were electrophoresed at constant voltage $(200 \mathrm{~V})$ under low ionic strength conditions (0.25x TBE buffer: $22 \mathrm{mM}$ Tris borate, $0.4 \mathrm{mM}$ EDTA) on $6 \%$ polyacrylamide gels. Gels were dried and subjected to standard autoradiographic procedures [30].

2.7. Protein Carbonyls. The levels of proteins carbonyl groups were determined by OxyBlot (Chemicon, USA). Briefly, after derivatization of carbonyl groups to dinitrophenylhydrazone (DNP-hydrazone) by reaction with dinitrophenylhydrazine (DNPH), the DNP-derivatized protein samples were separated by polyacrylamide gel electrophoresis followed by Western blotting as previously described [33].

2.8. Immunoprecipitation. Cell lysates containing $300 \mu \mathrm{g}$ of protein were mixed with Dynabeads protein G (Invitrogen, USA) and $2 \mu \mathrm{g}$ of polyclonal antibody against $\mathrm{Cx} 40$. Following immunoprecipitation of $\mathrm{Cx} 40$, the proteins were separated by SDS-PAGE, electrotransferred in a nitrocellulose membranes, and immunoblotted with $4 \mathrm{HNE}$ antibody.

2.9. Preparation of Cytoplasmic and Nuclear Extracts for Western Blotting. For cytoplasmic and nuclear extracts, cells were resuspended in $100 \mu \mathrm{L}$ of hypotonic buffer containing $10 \mathrm{mmol} / \mathrm{L}$ HEPES (pH 7.9), $10 \mathrm{mmol} / \mathrm{L} \mathrm{KCl}, 1.5 \mathrm{mmol} / \mathrm{L}$ $\mathrm{MgCl}_{2}, \quad 0.3 \%$ Nonidet $\mathrm{P}-40,0.5 \mathrm{mmol} / \mathrm{L}$ dithiothreitol, $0.5 \mathrm{mmol} / \mathrm{L}$ phenylmethylsulphonylfluoride, protease inhibitor cocktail, $1 \mathrm{mmol} / \mathrm{L}$ orthovanadate, and $5 \mathrm{mmol} / \mathrm{L}$ $\beta$-glycerophosphate. The lysates were incubated for $15 \mathrm{~min}$ on ice and then centrifuged at $1500 \times \mathrm{g}$ for $5 \mathrm{~min}$ at $4^{\circ} \mathrm{C}$ for collection of the supernatant containing cytosolic proteins. Pellets containing nuclei were resuspended in $50 \mu \mathrm{L}$ of extraction buffer containing $20 \mathrm{mmol} / \mathrm{L}$ HEPES ( $\mathrm{pH} 7.9$ ), $1.5 \mathrm{mmol} / \mathrm{L} \mathrm{MgCl}_{2}, 0.6 \mathrm{~mol} / \mathrm{L} \mathrm{KCl}, 0.2 \mathrm{mmol} / \mathrm{L} \mathrm{EDTA}, 20 \%$ glycerol, $0.5 \mathrm{mmol} / \mathrm{L}$ phenylmethylsulfonyl fluoride, protease inhibitor cocktail, $1 \mathrm{mmol} / \mathrm{L}$ orthovanadate, and $5 \mathrm{mmol} / \mathrm{L}$ $\beta$-glycerophosphate and then were incubated for $30 \mathrm{~min}$ on ice. Samples were then centrifuged at $13000 \mathrm{rpm}$ for $15 \mathrm{~min}$ to obtain supernatants containing nuclear fractions. Protein samples were separated by polyacrylamide gel electrophoresis followed by Western blotting. NFאB (Santa Cruz Biotechnology Inc., USA) was used as primary antibody.

2.10. $R T$-qPCR (Reverse Transcription Quantitative Real-Time $P C R)$. Total RNA from each sample was extracted with the AURUM Total RNA Mini Kit with DNAse digestion (BioRad Laboratories Inc., USA), according to the manufacturer's recommended procedure. After solubilization in RNAasefree water, total RNA was quantified by Bio-Rad SmartSpec Plus spectrophotometer (Bio-Rad Laboratories Inc., USA). First-strand cDNA was generated from $1 \mu \mathrm{g}$ of total RNA using iScript cDNA Synthesis Kit (Bio-Rad Laboratories Inc., USA). Primer pairs were obtained from PrimerBank from the Real-Time PCR Primer and Probe Database, RTPrimerDB, to hybridise to unique regions of the appropriate gene sequence. The reverse transcriptase (RT) PCR reactions were carried out using $1 \mu \mathrm{L}$ of cDNA in a $15 \mu \mathrm{L}$ total volume of PCR buffer (Invitrogen, Milan, Italy), containing $3 \mathrm{mM}$ $\mathrm{MgCl}_{2}, 300 \mu \mathrm{M}$ dNTPs, and $300 \mathrm{nM}$ of appropriate primers. Taq polymerase $(0.35 \mathrm{U})$ was also added. The amplification reactions were carried out in a thermal gradient cycler (Bio-Rad Laboratories Inc., USA) for 40 cycles. Each cycle consists of denaturation for $30 \mathrm{~s}$ at $94^{\circ} \mathrm{C}$, annealing for $30 \mathrm{~s}$ at $60^{\circ} \mathrm{C}$, and extension for $30 \mathrm{~s}$ at $72^{\circ} \mathrm{C}$. A final extension step at $72^{\circ} \mathrm{C}$ for $5 \mathrm{~min}$ terminates the amplification. For each amplification, two controls were performed: (i) RT-PCR mixture with no reverse transcriptase to control for genomic DNA contamination and (ii) PCR mixture with no cDNA template, to check for possible external contamination. A $5 \mu \mathrm{L}$ sample of the PCR reaction was electrophoresed on an ethidium bromide containing $2 \%$ agarose gel by the use of the Bio-Rad Subcell GT system. Quantitative Real-Time PCR (qPCR) was performed using SYBR Green on iQ5 Multicolor Real-Time PCR Detection System (Bio-Rad Laboratories Inc., USA). The final reaction mixture contained $1 \mu \mathrm{L}$ of cDNA, $300 \mathrm{nM}$ of each primer, $7.5 \mu \mathrm{L}$ of iQ SYBR Green Supermix (Bio-Rad Laboratories Inc., USA), and RNAse-free water to complete the reaction mixture volume to $15 \mu \mathrm{L}$. All reactions were run as triplicates. The QPCR was performed with a hot-start denaturation step at $95^{\circ} \mathrm{C}$ for $3 \mathrm{~min}$ and then was carried out for 40 cycles at $95^{\circ} \mathrm{C}$ for $10 \mathrm{~s}$ and at $60^{\circ} \mathrm{C}$ for $20 \mathrm{~s}$. The fluorescence was read during the reaction by the Opticon Monitor 3 software (Bio-Rad Laboratories Inc., USA), allowing a continuous monitoring of the amount of PCR products. Primers are initially used to generate a standard curve over a large dynamic range of starting cDNA quantity which allows calculating the amplification efficiency (a critical value for the correct quantification of expression data) for each of the primer pairs. The melting curve analysis was performed at the end of each experiment to verify that a single product for primer pair is amplified (data not shown). As to control experiments, gel electrophoresis was also performed to verify the sizes of the amplified QPCR products. Ribosomal proteins L13a (RPL13a), L11a (RPL11a), and GAPDH were used in our experiments as internal standards. Samples were compared using the relative cycle threshold (CT) method. The fold increase or decrease was determined relative to a control after normalising to RPL13a 
TABLE 1: Cellular viability as measured by trypan blue assay.

\begin{tabular}{lc}
\hline Samples & Cell viability (\%) \\
\hline Control & $89 \% \pm 15$ \\
CS $50 \mathrm{~min}$ & $78 \% \pm 12$ \\
CS $6 \mathrm{hr}$ & $69 \% \pm 21$ \\
CS $24 \mathrm{hr}$ & $62 \% \pm 18$ \\
\hline
\end{tabular}

(internal standard). The formula $2-\Delta \Delta \mathrm{CT}$ was used, where $\Delta \mathrm{CT}$ is gene of interest CT (RPL13A CT) and $\Delta \Delta \mathrm{CT}$ is $\Delta \mathrm{CT}$ experimental $(\triangle \mathrm{CT}$ control).

2.11. Ultrastructural Analysis. Cells were scraped and collected in $0.1 \mathrm{M}$ cacodylate buffer $(\mathrm{pH} \mathrm{7.4)}$ ) and then spun in $1.5 \mathrm{~mL}$ tubes at $2000 \times \mathrm{g}$ for $5 \mathrm{~min}$. Pellets were fixed with $2.5 \%$ glutaraldehyde in $0.1 \mathrm{M}$ sodium cacodylate buffer for $4 \mathrm{hr}$ at $4^{\circ} \mathrm{C}$. They were then washed with $0.1 \mathrm{M}$ cacodylate buffer $(\mathrm{pH}$ 7.4) three times and postfixed in $1 \%$ osmium tetroxide and $0.1 \mathrm{M}$ cacodylate buffer at $\mathrm{pH} 7.4$ for $1 \mathrm{hr}$ at room temperature. The specimens were dehydrated in graded concentrations of ethanol and embedded in epoxide resin (Agar Scientific, 66A Cambridge Road, Stansted Essex CM24 8DA, UK).

Cells were then transferred to latex modules filled with resin and subsequently thermally cured at $60^{\circ} \mathrm{C}$ for $48 \mathrm{hr}$.

Semithin sections $(0.5-1 \mu \mathrm{m}$ thickness) were cut using an ultramicrotome (Reichard Ultracut S, Austria) stained with toluidine blue, and blocks were selected for thinning. Ultrathin sections of about 40-60 nm were cut and mounted onto formvar-coated copper grids. These were then doublestained with $1 \%$ uranyl acetate and $0.1 \%$ lead citrate for $30 \mathrm{~min}$ each and examined under a transmission electron microscope, Hitachi H-800 (Tokyo, Japan), at an accelerating voltage of $100 \mathrm{KV}$.

2.12. Statistical Analysis. For each of the variables tested, twoway analysis of variance (ANOVA) was used. A significant result was indicated by a $P$ value $<0.05$. Data are expressed as mean $\pm \mathrm{SD}$ of triplicate determinations obtained in 5 independent experiments.

\section{Results}

3.1. Cytotoxic Effect of CS on Human Lung Epithelial Calu3 Cells. The first step of the study was to evaluate Calu-3 cytotoxicity induced by CS. After CS exposure, media were collected at different time points (from $50 \mathrm{~min}$ to $24 \mathrm{hr}$ ) and the lactate dehydrogenase $(\mathrm{LDH})$ release from the cells was measured. As shown in Figure 1, CS induced a significant release of LDH already after 50 min of CS exposure (2-fold) and this effect was even more pronounced after $24 \mathrm{hr}$ leading to 7 -fold increase of $\mathrm{LDH}$ release with respect to the air exposed cells (the same results were obtained by trypan blue exclusion assay, Table 1).

3.2. CS Exposure Induced Cells Detachment. Ultrastructural study was performed to better evaluate the status of the cells exposed to CS and by transmission electronic microscopy

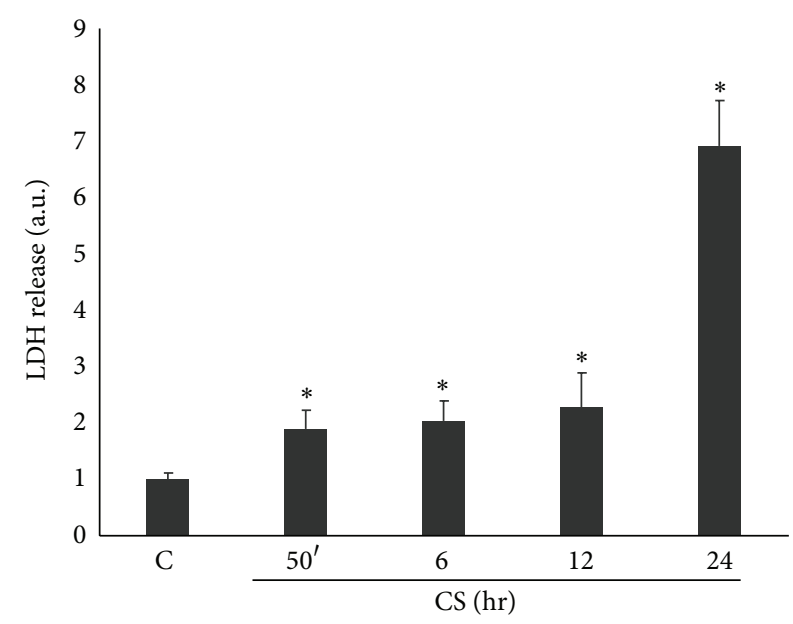

FIgure 1: CS induces toxicity in Calu-3 cells. Cells were exposed to CS for 50 minutes and media were collected at different time points (50 min-24 hr). The graph shows evidence of toxicity in cells exposed to CS as measured by LDH release in the media. Data shown are representative of five independent experiments. $P<0.05$; versus $\mathrm{C}$.

(TEM). As shown in Figure 2, control cells (C) appeared with a normal cellular structure and a clear cell-to-cell contact. After CS exposure the cells started to form internal vesicles (50 min, $2 \mathrm{hr}$ ) and to lose intercellular contacts in a timedependent manner ( 6 and $24 \mathrm{hr}$ ), as evidenced by the red arrows in the representative image.

3.3. Evidence of Oxidized Proteins in Calu-3 Cells Exposed to CS. Calu-3 cells exposed to CS showed increase levels of oxidative stress as determined by the protein oxidation and lipid peroxidation products formation. Carbonyl proteins (Figure 3(a)) levels were significantly higher immediately after CS exposure, reaching the highest levels 50 minutes after CS exposure. In addition, CS induced the formation of 4hydroxynonenal (4HNE) protein adducts (Figure 3(b)) after CS exposure in a time-dependent manner (2-fold at $50 \mathrm{~min}$ and 6 -fold at $24 \mathrm{hr}$ ).

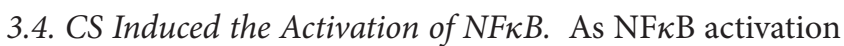
is determined by the translocation of p65/p50 subunits to the nucleus, Western blotting for $\mathrm{p} 65$ subunit was performed on nuclear protein extracts from Calu-3 cells exposed to CS. As shown in Figure 4, CS determined a 2-fold increase in p65 nuclear protein levels at the earlier time points after CS exposure. On the contrary, no evidence of $\mathrm{NF} \kappa \mathrm{B}$ activation was found at the later time points (i.e., 12 and $24 \mathrm{hr}$ exposure), suggesting an early $\mathrm{NF} \kappa \mathrm{B}$ activation by $\mathrm{CS}$ exposure.

3.5. Corilagin Reduces the Cytotoxicity Induced by CS Exposure. The next step of our study was to investigate whether corilagin could have a protective effect against CS induced toxicity in Calu-3 cells. The dose of corilagin was chosen based on the literature and on preliminary studies where its toxicity was evaluated in the $0-100 \mu \mathrm{M}$ concentrations range (data not shown). As shown in Figure 5, corilagin 


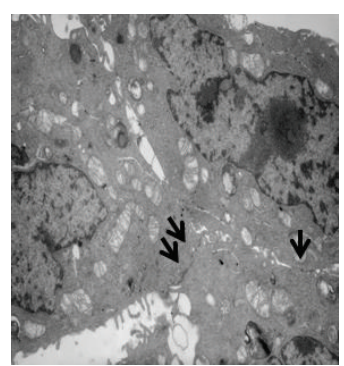

C

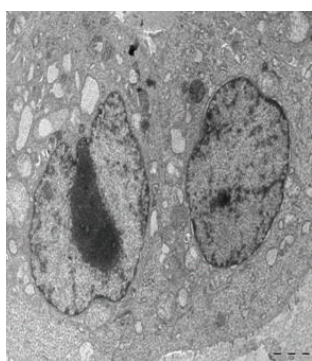

$50^{\prime}$

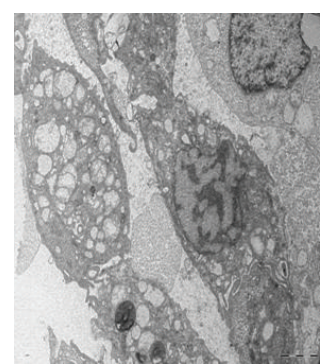

2

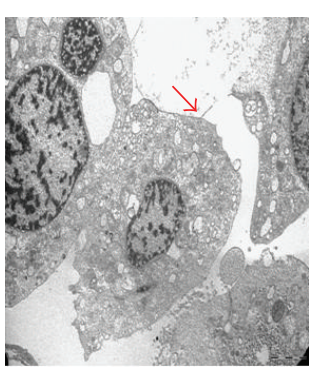

6

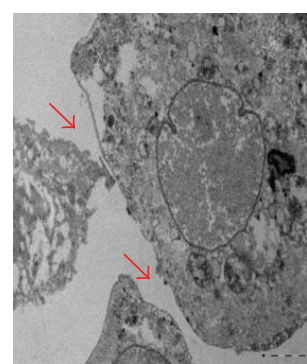

24

CS (hr)

Figure 2: Cells lose intercellular contact after CS exposure. Control cells are well assembled and show the presence of densifications in the contact regions between them (see black arrows). At later time points (12 and $24 \mathrm{hr}$ ) the loss of cell-to-cell contact is clear as shown by red arrows. Pictures are taken at different magnifications.
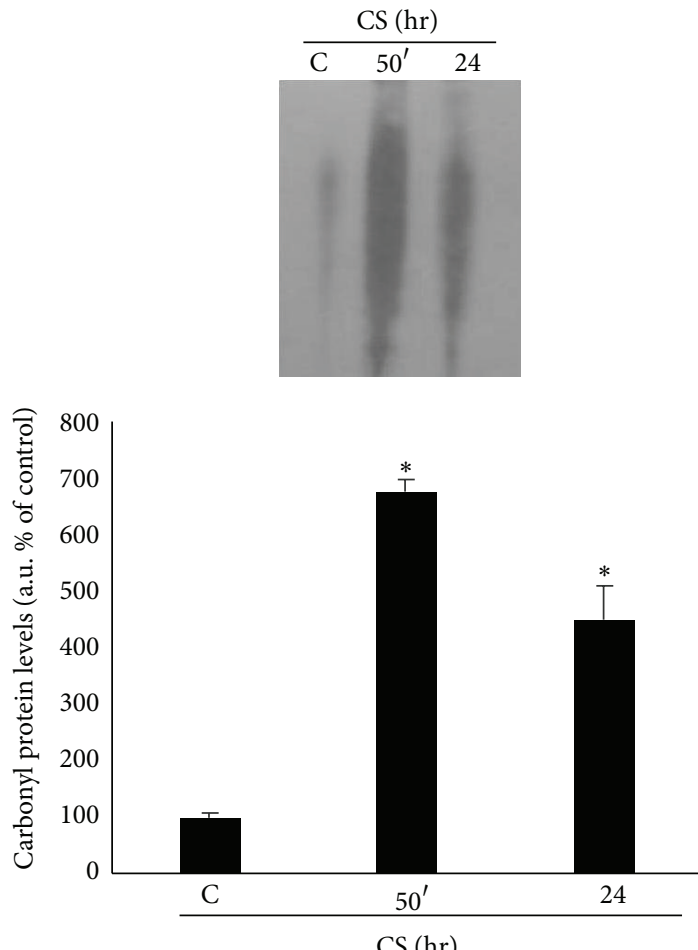

(a)
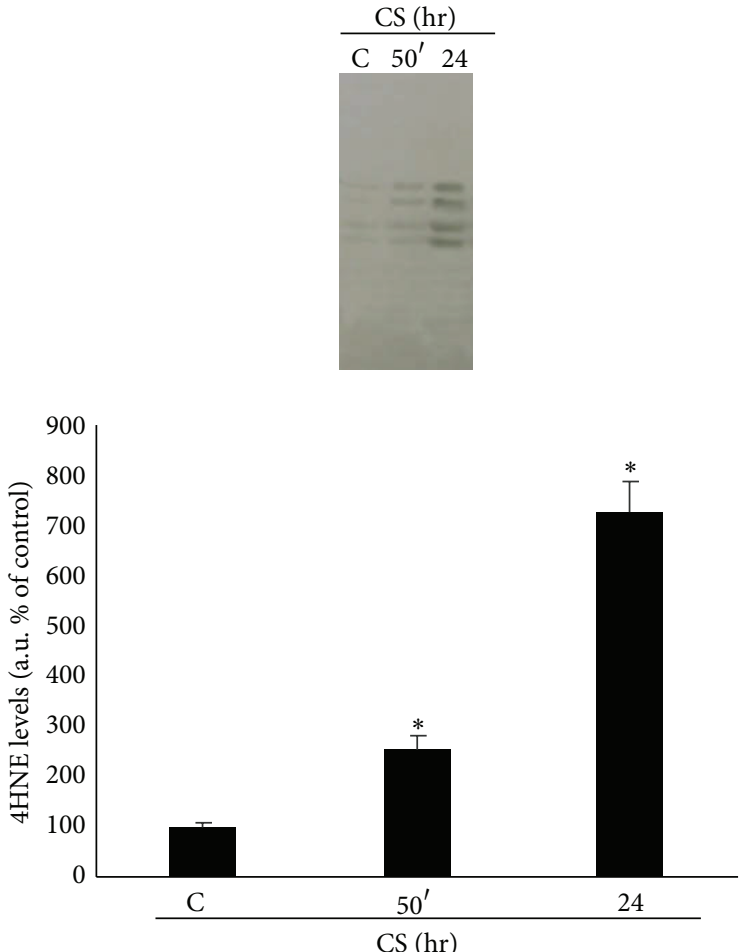

(b)

FIGURE 3: CS promotes proteins oxidation and lipid peroxidation. WBs in the top panel are representative of five independent experiments. Quantification of carbonyl proteins is shown in the bottom left panel (a) and quantification of 4HNE is shown in the bottom right panel (b). Data are expressed as arbitrary units (average of five independent experiments; $P<0.05$; * versus C).

pretreatment reduced about $30-50 \%$ the cytotoxicity induced by CS exposure as measured by LDH release compared to control cells (Figure 5).

3.6. Pretreatment with Corilagin Prevents CS Induced Loss of Cell-to-Cell Contacts. As shown in Figure 6, pretreatment with $10 \mu \mathrm{M}$ of corilagin prevented CS induced loss of cell-tocell contacts. This effect was evident at all the time points as shown by the black arrows in Figure 6 .
3.7. Pretreatment with Corilagin Prevents CS Induced Proteins Oxidation. Calu-3 cells pretreated with corilagin showed significantly decreased levels of carbonyl proteins induced by CS of about $50 \%$ during the analyzed time points (Figure $7(\mathrm{a})$ ). The same effect was observed for the formation of $4 \mathrm{HNE}$ protein adducts as shown in Figure 7(b), with a level of 4HNE almost back to the control levels in the cells pretreated with corilagin. These data confirm that corilagin operates on early CS-mediated changes (see in particular Figure 7(a)). 


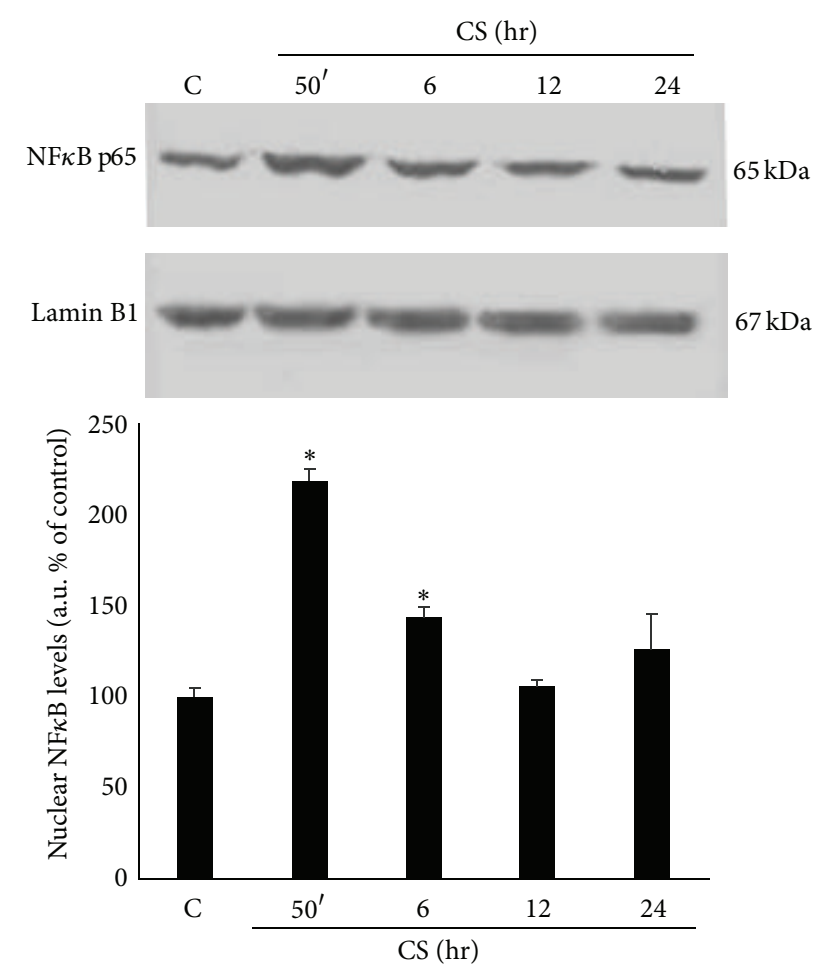

FIgURE 4: CS exposure activates NFkB. WB in the top panel is representative of five independent experiments. In the bottom panel is shown the quantification of nuclear $\mathrm{NF} \kappa \mathrm{B}$ protein levels. Data are expressed as arbitrary units (average of five independent experiments; $P<0.05$; * versus $\mathrm{C}$ ). Lamin $\mathrm{B} 1$ was used as loading control.

3.8. Corilagin Prevents CS Induced Connexin 40 Expression. As connexin $40(\mathrm{Cx} 40)$ is a protein present in cellular gap junctions, we evaluated whether its expression is affected by CS exposure in Calu-3 cells. As shown in Figure 8(a), the protein levels of $\mathrm{Cx} 40$ decreased upon CS exposure starting at $12 \mathrm{hr}$, while corilagin pretreatment partially prevented this decrease. In parallel, as it is depicted in Figure 8(b), Cx40 gene expression started to increase significantly in a timedependent manner after $6 \mathrm{hr}$ from CS exposure (7-fold) and it returned to the control levels at the later time points (12$24 \mathrm{hr}$ ) in cells pretreated with corilagin.

This effect was not noticed for connexin 43 (Cx43), another protein present in the gap junctions, as it is shown in Figure 9.

3.9. Corilagin Prevents CS Induced Cx40-4HNE Adduct Formation. Since $4 \mathrm{HNE}$ can bind to the proteins - $\mathrm{SH}$ groups and $\mathrm{Cx} 40$ contains several cysteine amino acids ( $-\mathrm{SH}$ group), the formation of $\mathrm{Cx} 40-4 \mathrm{HNE}$ adducts was evaluated by immunoprecipitation upon CS exposure with/without the presence of corilagin. As shown in Figure 10, there was a clear and significant formation of $4 \mathrm{HNE}-\mathrm{Cx} 40$ adducts (2.5-fold) after CS exposure and this effect was clearly prevented by corilagin pretreatment.

3.10. Corilagin Inhibits CS Induced NFאB Activation. The reason for analyzing the effects of corilagin on $\mathrm{NF} \kappa \mathrm{B}$ was

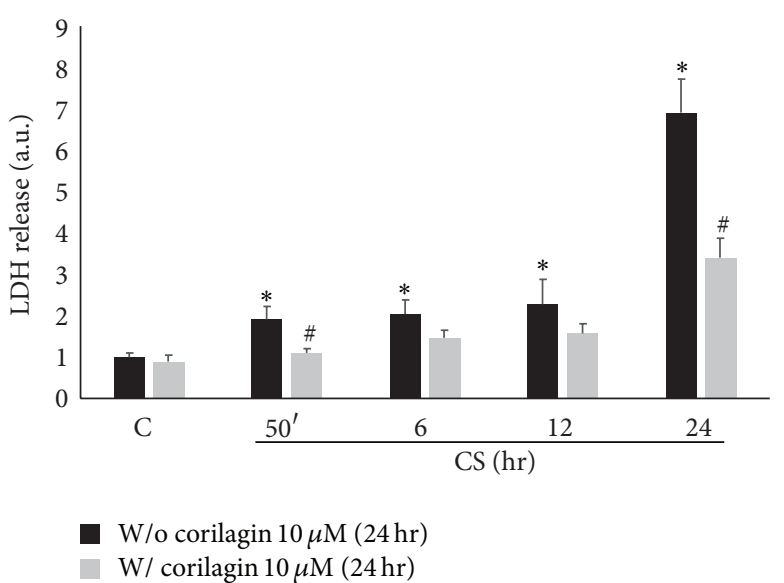

FIGURE 5: Corilagin pretreatment modulates the toxic effect of CS. The graph shows LDH release after CS exposure from cells pretreated or not with corilagin. Lower LDH levels are evident at all time points in cells pretreated. Data is representative of five independent experiments. $P<0.05 ; *$ versus $0 \mathrm{hr}$ w/o corilagin $10 \mu \mathrm{M}$ (24 hr); \# versus w/o corilagin $10 \mu \mathrm{M}(24 \mathrm{hr})$.

based on (a) the evidence that CS induces activation of $\mathrm{NF} \kappa \mathrm{B}$ (see Figure 4) and (b) the reported finding that the promoter of the connexin 40 gene (GJA5) has $\mathrm{NF} \kappa \mathrm{B}$ consensus binding sequences, suggesting a $\mathrm{NF} \kappa \mathrm{B}$ dependent transcriptional regulation [33]. In addition, corilagin was reported to prevent $\mathrm{NF} \kappa \mathrm{B}$ activation and regulate $\mathrm{NF} \kappa \mathrm{B}$ dependent gene expression in a different experimental model system [26]; we have analyzed whether also in this cellular and experimental model corilagin could prevent CS induced $\mathrm{NF} \kappa \mathrm{B}$ activation and function. Indeed, as it is shown in Figure 11, cells pretreated with corilagin showed a clear and significant inhibition of $\mathrm{NF} \kappa \mathrm{B}$ activation induced by CS (4fold at $50 \mathrm{~min}$ and 2 -fold at $6-24 \mathrm{hr}$ ), as measured by 65 nuclear translocation. Furthermore, corilagin was able to inhibit, although with a slightly different efficiency, the $\mathrm{NF} \kappa \mathrm{B}$ interaction to oligonucleotides mimicking the two major $\mathrm{NF} \kappa \mathrm{B}$ consensus sequences (Figures 11(b) and 11(c)).

\section{Discussion}

The results presented in this study underlined the effects that CS has on lung epithelial cells, with focus on cellular junctions, and how a polyphenolic compound, corilagin, can attenuate these effects.

The respiratory tract is a complex system important for the process of respiration and it allows the direct contact between human body and external oxidative environment that can be noxious to lung tissues. Indeed, lung functionality is maintained thanks to the RTLF (respiratory tract lining fluid), which is rich in antioxidants compounds, and to the compact epithelium, composed of cells containing multiple junctions [34].

Therefore, lung epithelium, when intact, is able to protect the respiratory tract from outdoor stressors [35]. Nowadays, many studies focus on the composition of the environmental air as source of damage for human health. Pollutants such as 


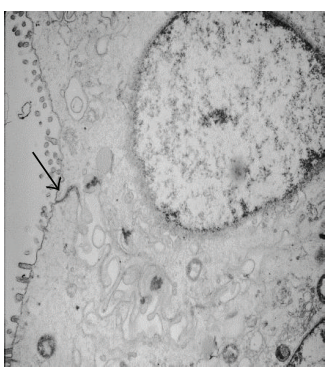

C

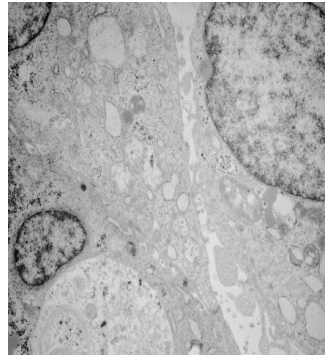

$50^{\prime}$

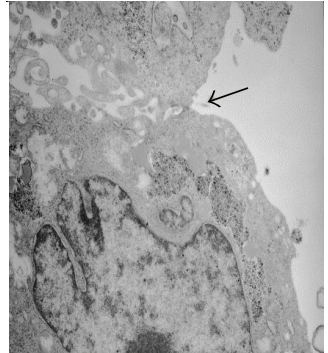

2

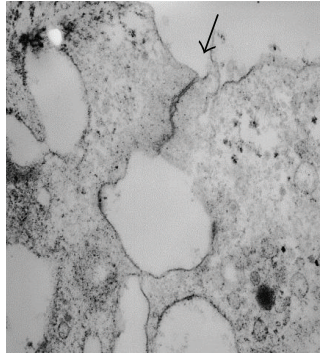

6

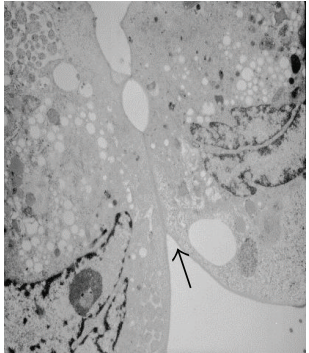

24

Corilagin $10 \mu \mathrm{M}$

CS (hr)

FIGURE 6: Corilagin prevents the loss of cell-to-cell contacts induced by CS. CS exposure leads to the formation of vesicles inside the cells; piled structures keeping cells together are still visible after 2, 6, and $24 \mathrm{hr}$ from exposure (see black arrows). Pictures are taken at different magnifications.

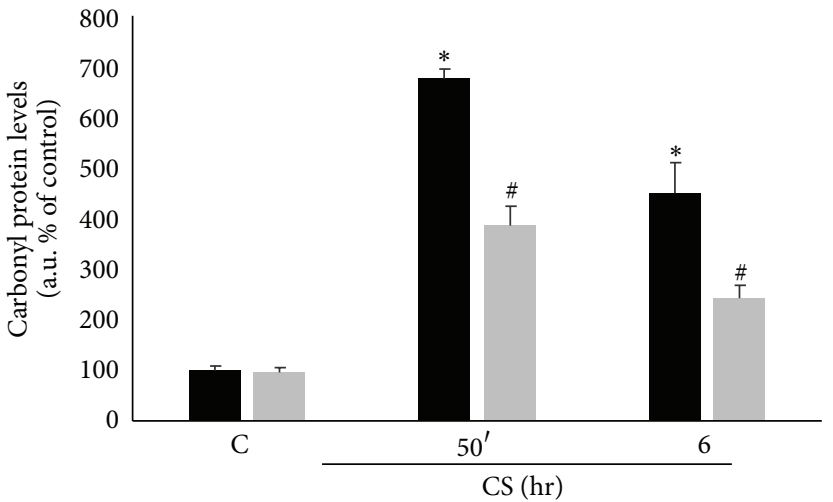

W/o corilagin $10 \mu \mathrm{M}(24 \mathrm{hr})$

$\mathrm{W} /$ corilagin $10 \mu \mathrm{M}(24 \mathrm{hr})$

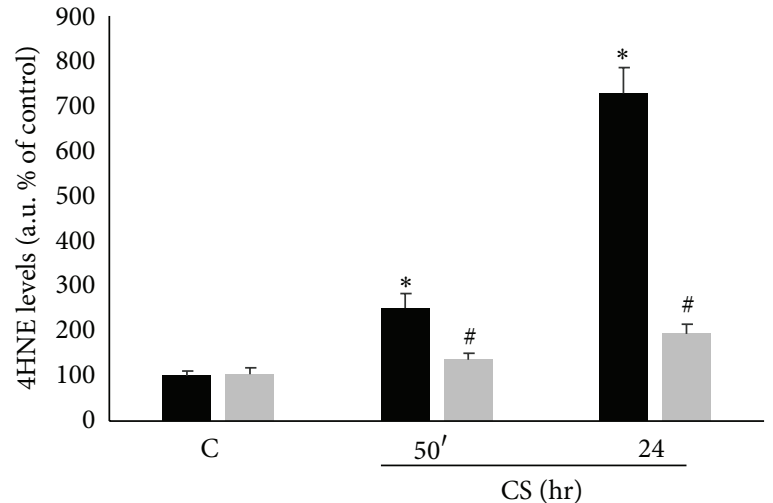

W/o corilagin $10 \mu \mathrm{M}(24 \mathrm{hr})$

$\mathrm{W} /$ corilagin $10 \mu \mathrm{M}(24 \mathrm{hr})$

(a)

(b)

FIGURE 7: CS induced oxidative markers are modulated by corilagin. The WBs shown on the top are representative of five different experiments. Quantification of carbonyl proteins is shown in the bottom left panel (a) and quantification of $4 \mathrm{HNE}$ is shown in the bottom right panel (b). Data are expressed as arbitrary units (average of five independent experiments; $P<0.05$ ). * versus $0 \mathrm{hr}$ w/o corilagin $10 \mu \mathrm{M}$ (24 hr); \# versus w/o corilagin $10 \mu \mathrm{M}(24 \mathrm{hr})$.

ozone [36], ambient particles [37], and cigarette smoke (CS) [38] are among the most toxic to which living organisms are continuously exposed.

It is well documented that CS is toxic on airway cells, especially due to oxidative damage [39]. In our study we used LDH as a marker of cytotoxicity in Calu- 3 cells and we observed increased levels of LDH in cells exposed to CS, confirming the noxious effect that CS has on the airways epithelium. LDH is released from cells mostly after damage to the cellular membrane and often is correlated to necrosis cellular process. In our experimental procedure, as previously published [29], the cell number did not vary in a significant manner as demonstrated by the trypan blue assay; therefore we have analyzed the cells by TEM in order to evaluate the cellular morphology changes induced by CS. Of interest was the fact that the cells exposed to CS clearly showed a loss in cell-to-cell contact. This result is in line with previous work by Upham et al. showing that CS inhibited the formation of gap junctions via the activation of extracellular receptor kinase in liver epithelial cells of WB-F344 rat [40]. In addition, a previous work has shown that oxidative stress induced by cigarette smoke extract (CSE) or $\mathrm{H}_{2} \mathrm{O}_{2}$ (which is also present in CS) is able to induce the opening of gap junction hemichannels: this will cause membrane depolarization and the opening of the hemichannels will facilitate the entry of toxic molecules that in turn can injure the cells [41]. In our study we were not able to detect a significant cell death but this could be just a matter of timing and CS doses. In fact, in the study of Ramachandran, the authors have used a high dose of $\mathrm{H}_{2} \mathrm{O}_{2}(1 \mathrm{mM})$ and CSE concentrated that has a quite different composition from freshly smoked CS used in our experiments. In addition, in our previous work we detected a 


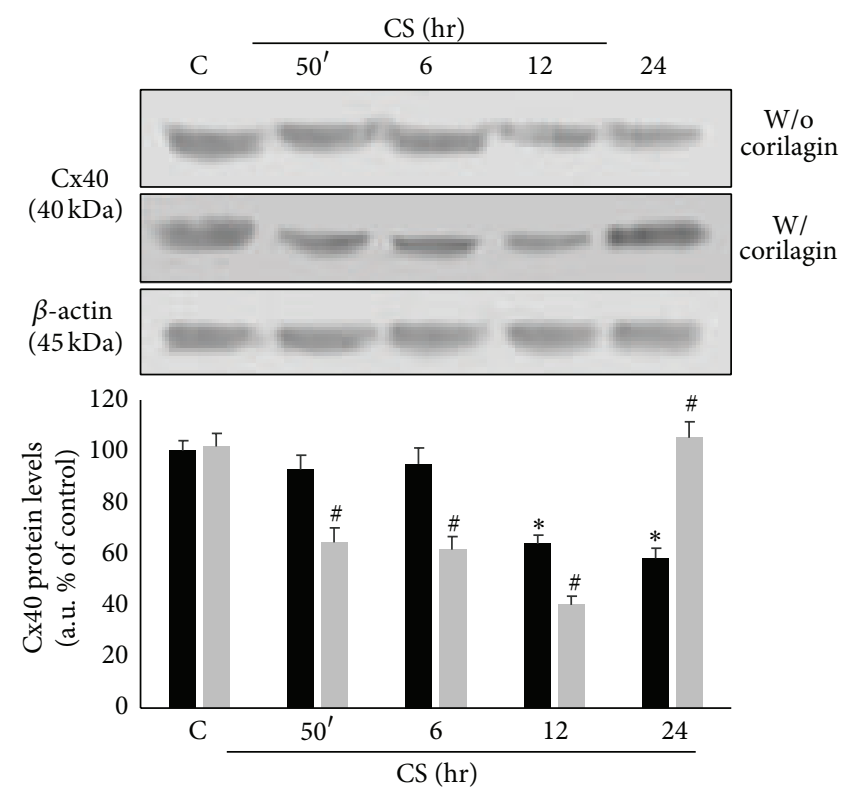

W/o corilagin $10 \mu \mathrm{M}(24 \mathrm{hr})$ $\mathrm{W} /$ corilagin $10 \mu \mathrm{M}(24 \mathrm{hr})$

(a)

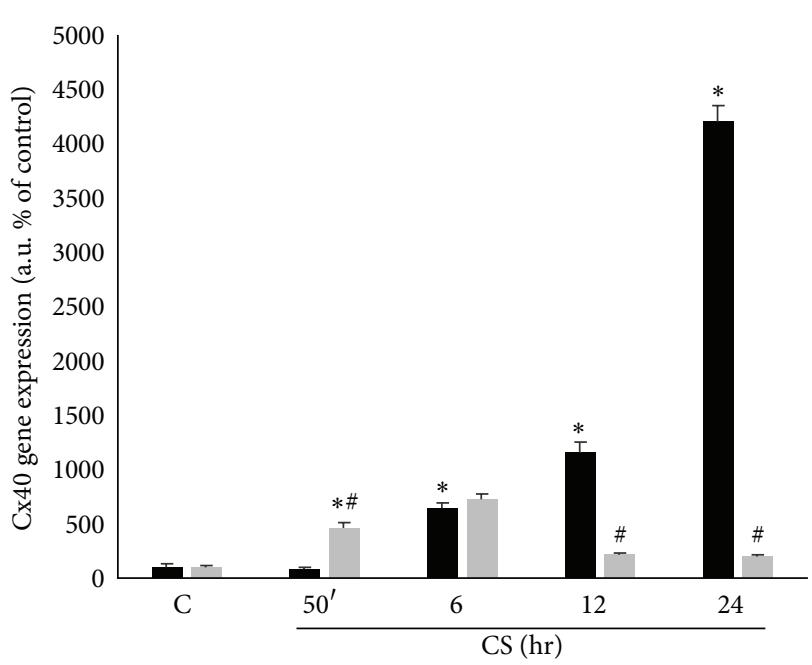

W/o corilagin $10 \mu \mathrm{M}(24 \mathrm{hr})$ $\mathrm{W} /$ corilagin $10 \mu \mathrm{M}(24 \mathrm{hr})$

(b)

FIGURE 8: Corilagin reestablishes connexin 40 protein and gene levels after CS exposure. WBs in the top left panels are representative of five independent experiments. Bands quantification is shown in the bottom left panel (a). $\beta$-actin was used as loading control. Gene expression is shown in the right panel (b). Data are expressed as arbitrary units (average of five independent experiments; $P<0.05$ ); $*$ versus 0 hr w/o corilagin $10 \mu \mathrm{M}(24 \mathrm{hr})$; \# versus w/o corilagin $10 \mu \mathrm{M}(24 \mathrm{hr})$.

concentration of $\mathrm{H}_{2} \mathrm{O}_{2}$ in CS ranging from 30 to $100 \mu \mathrm{M}$ [37], which is much lower than the one used by Ramachandra et al. [41].

Gap junctions and connexins, in particular, are important not only in cellular communication but also in cell-to-cell adhesion. Among the most representative connexins in the lung, there are connexin $40(\mathrm{Cx} 40)$ and connexin $43(\mathrm{Cx} 43)$ $[42,43]$. We have shown that CS was able to decrease the levels of $\mathrm{Cx} 40$ in a time-dependent manner and this is in parallel with the induction of new $\mathrm{Cx} 40$ mRNA, which could be interpreted as a protective cellular response of the cells to the loss of the protein. In addition this confirms the fact that the cells were alive and able to start the new transcripts. Whether the CS-mediated effects on $\mathrm{Cx} 40$ and $\mathrm{Cx} 43$ are NF$\kappa \mathrm{B}$ dependent remains to be determined.

Our work is in agreement with many other studies showing that oxidative stress, in specific CS, is able to induce the activation of $\mathrm{NF} \kappa \mathrm{B}$ [44]. Its activation can be measured indirectly by analyzing the nuclear translocation of its cytoplasmic subunits among which there is p65. We have shown that the nuclear level of p65 in Calu-3 cells after CS exposure was significantly increased, demonstrating the activation of $\mathrm{NF} \kappa \mathrm{B}$ by $\mathrm{CS}$ in airway epithelial cells. On the other hand, we have demonstrated that corilagin inhibits $\mathrm{NF} \kappa \mathrm{B}$ activation and has important effects on the interactions between $\mathrm{NF} \kappa \mathrm{B}$ and $\mathrm{DNA}$. As far as $\mathrm{NF} \kappa \mathrm{B}$ activation, it is possible that this is the consequence of CS induced oxidative stress as demonstrated by the increased levels of protein carbonyls formation and also by the increased levels of $4 \mathrm{HNE}$-protein adducts. We have observed that when the cells were exposed to CS for $50 \mathrm{~min}$, the levels of carbonyl proteins increased quickly, indicating that CS led to the oxidation of proteins. Similar response was observed in the case of $4 \mathrm{HNE}$ adducts, as CS induced lipid peroxidation and formation of $\alpha, \beta$-unsaturated aldehydes.

Our study suggests another possible mechanism by which CS can affect gap junction besides the one elegantly proposed by Ramachandra et al.; that is, the loss of gap junction is a consequence of the formation of $4 \mathrm{HNE}$-connexin adducts. In fact, since CS induced the formation of $4 \mathrm{HNE}$, this aldehyde is able to bind to Cys, His, or Lys residues via Michael addition that are present in large amount in $\mathrm{Cx} 40$. Our data demonstrated that $\mathrm{Cx} 40$ was able to form adducts with $4 \mathrm{HNE}$ and this could be the reason of the protein loss that, once modified by $4 \mathrm{HNE}$, can be degraded by the proteasome [37]. This effect seems to be related only to Cx40; in fact neither $\mathrm{Cx} 43$ protein levels nor its mRNA levels were affected by CS exposure. This is corroborated by a study showing that connexin expression is frequently disrupted in response to lung pathology; for instance, during the acute phase of lung injury, $\mathrm{Cx} 43$ expression does not decrease while $\mathrm{Cx} 40$ expression decreases [45].

The connexins, when present in the same cells, can form heterodimers in the gap junctions channels as demonstrated 


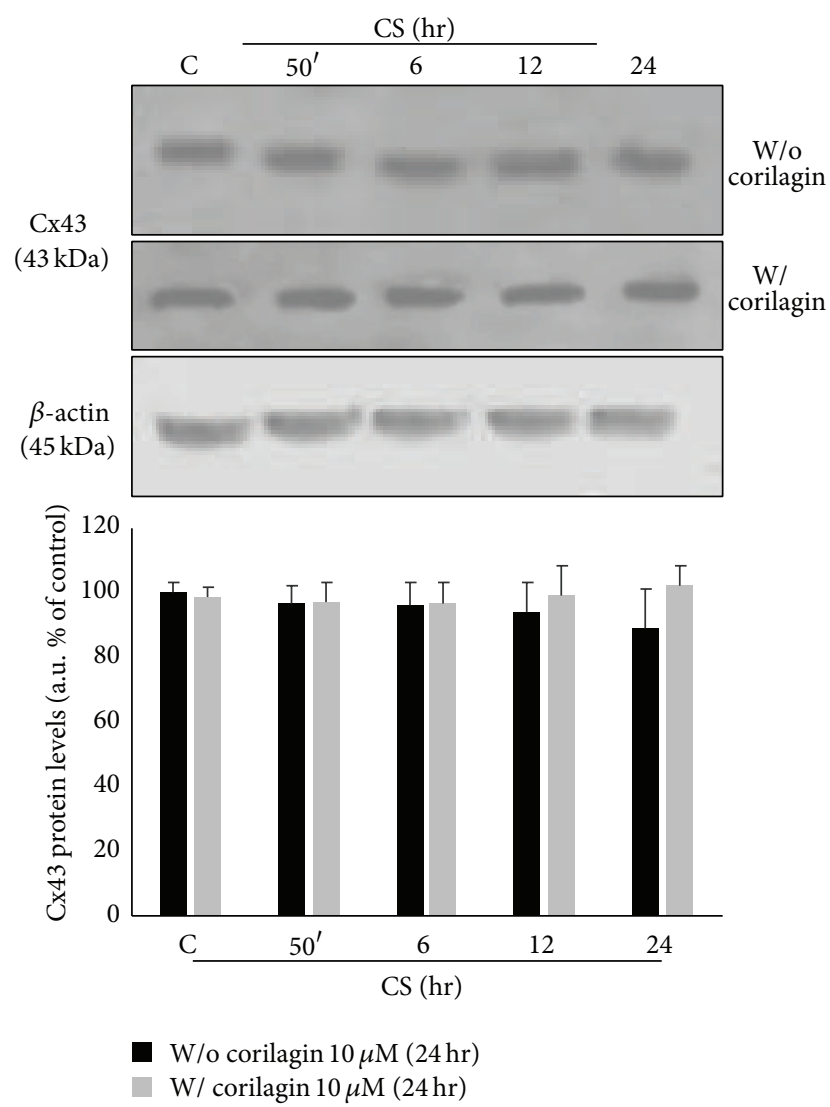

FIgURE 9: Effect of CS and corilagin in $\mathrm{Cx} 43$ protein levels. Top panel shows representative WBs of five independent experiments. Bands quantification is shown in the bottom panel. $\beta$-actin was used as loading control.

for $\mathrm{Cx} 40 / \mathrm{Cx} 43, \mathrm{Cx} 37 / \mathrm{Cx} 43$, and $\mathrm{Cx} 40 / \mathrm{Cx} 37$ [46]; therefore it is possible that the loss of just one kind of connexin, in our case Cx40, can affect the functionality of several gap junctions.

A recent study confirms anyways the importance of $\mathrm{Cx} 40$ in lung structure; in fact using animal $\mathrm{KO}$ for $\mathrm{Cx} 40$ the authors have shown that the animals developed severe lung abnormalities such as fibrosis and altered alveolar remodeling [47].

In the second part of our study the possible protective effect of the polyphenol corilagin on CS induced cell damage and loss of gap junctions has been evaluated. Corilagin is a polyphenolic compound known for its strong ability of inhibiting $\mathrm{NF} \kappa \mathrm{B}$ activation [26]. The results of the study confirm that corilagin inhibits CS induced $\mathrm{NF} \kappa \mathrm{B}$ activation. The protective effect of corilagin against lung injury in a bleomycin model has been recently demonstrated [48] together with its ability to quench free radicals and inhibit $\mathrm{NF} \kappa \mathrm{B}[49,50]$. In addition, pretreatment with corilagin was able to counteract CS induced protein oxidation and lipid peroxidation, as determined by carbonyl proteins formation and 4 HNE proteins adducts. Furthermore, corilagin was also able to prevent the loss of $\mathrm{Cx} 40$, most likely thanks to its

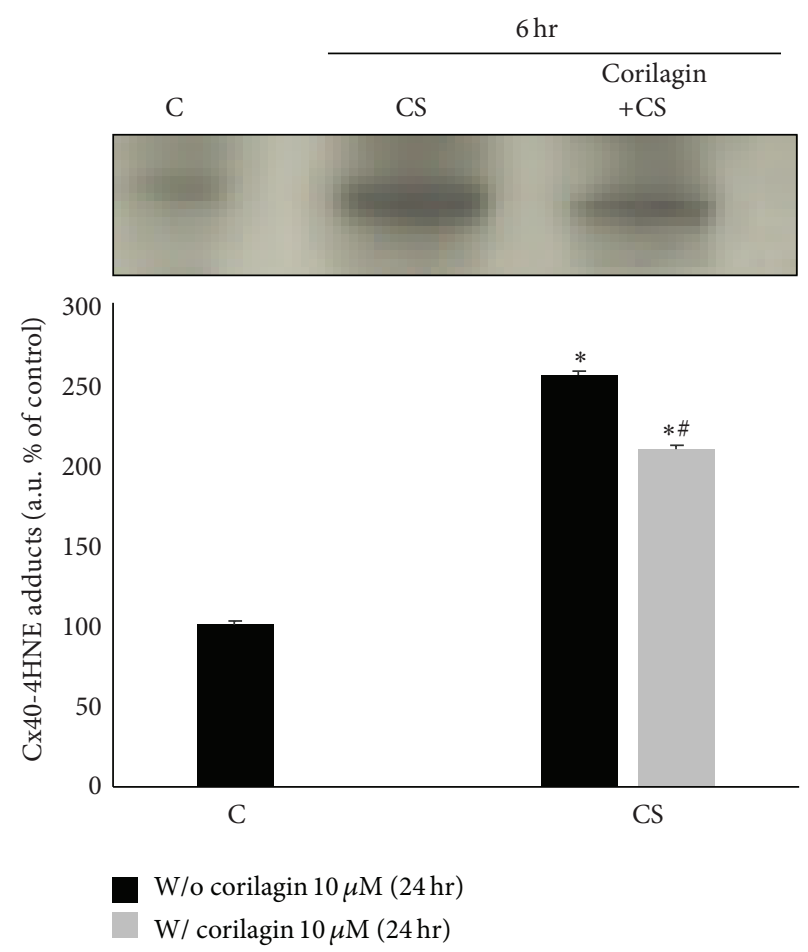

FIGURE 10: Corilagin reduces the formation of $4 \mathrm{HNE}-\mathrm{Cx} 40$ adducts induced by exposure to CS. WB in the top panel is representative of five independent experiments. Bands quantification is shown in the bottom panel. Data are expressed as arbitrary units, average of five independent experiments; $P<0.05 . *$ versus $C$; \# versus CS.

free radical quenching properties, therefore preventing the formation of $\mathrm{Cx} 40-4 \mathrm{HNE}$-protein adducts.

In parallel, $\mathrm{Cx} 40$ gene expression appeared to be less enhanced by CS when Calu-3 cells were pretreated with the polyphenol as a consequence of the effect of corilagin on preventing $\mathrm{Cx} 40$ protein loss. Interestingly, the promoter of connexin 40 (GJA5) has NF- $\kappa$ B consensus binding sequences, suggesting a $\mathrm{NF} \kappa \mathrm{B}$ dependent transcriptional regulation [33]. However, further work is necessary to verify whether the reduced transcription of $\mathrm{Cx} 40$ in the presence of corilagin is dependent on the inhibitory effects of corilagin on NF$\kappa \mathrm{B}$. In any case and whatever the molecular basis of the corilagin-mediated effects is, TEM analysis showed that treatment with corilagin prevented the loss of cell-to-cell junctions, enforcing the theory of $\mathrm{Cx} 40-\mathrm{Cx} 43$ heterodimers gap junctions presence in airway epithelium, since $\mathrm{Cx} 43$ protein expression was not affected by CS exposure. Of note is that in the present study corilagin was used at the concentration of $10 \mu \mathrm{M}$ which although used in other studies present in the literature $[24,26]$ could be a dose difficult to reach in the lung tissue due to its bioavailability. Therefore, we could suggest the use of corilagin by nebulization, to avoid its degradation in the GI tract and to reach higher doses in the respiratory tract.

Altogether, the results presented in our study showed that CS is able to damage airway epithelium integrity by causing cellular junctions loss through oxidative damage 


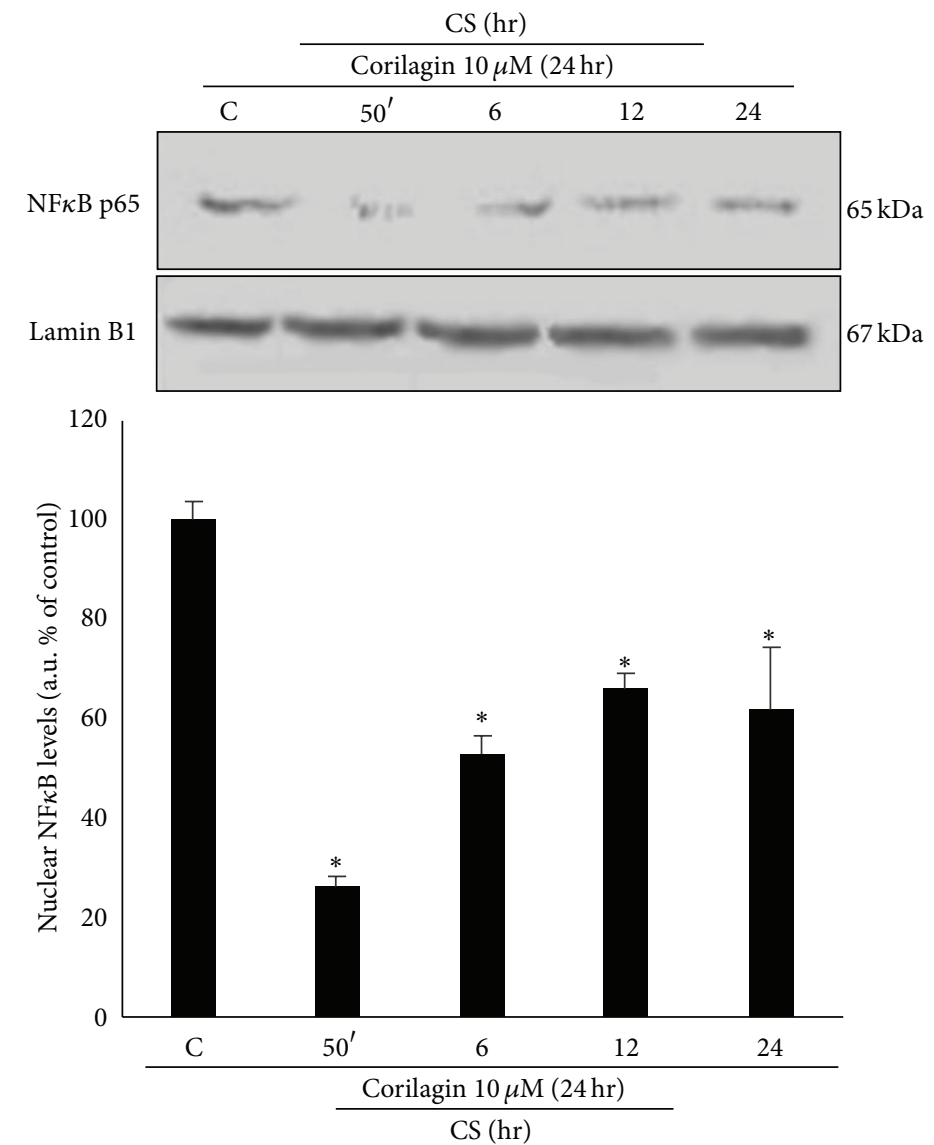

(a)

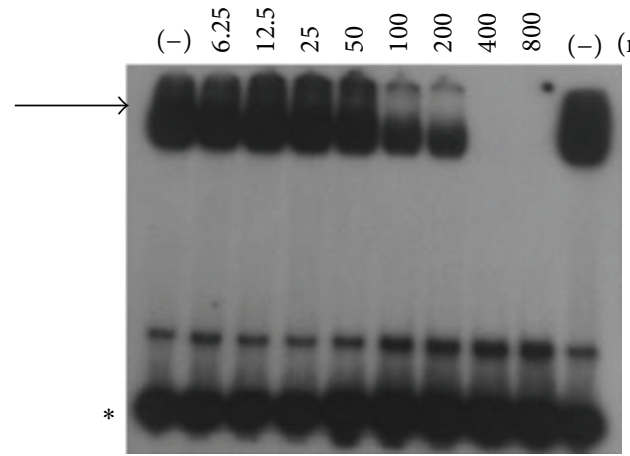

(b)

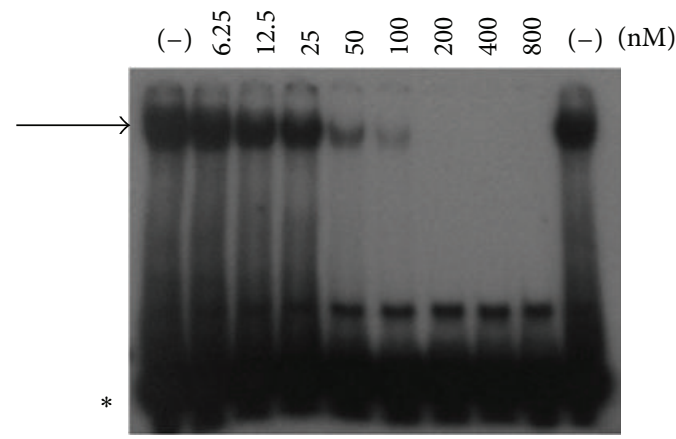

(c)

FIGURE 11: Effects of corilagin on NFKB. $24 \mathrm{hr}$ of pretreatment with corilagin decreases the activation of NF $\kappa \mathrm{B}$ induced by CS. WB shown in the top panel (a) is representative of five independent experiments. In the bottom of panel (a) is shown the quantification of nuclear NF $\kappa \mathrm{B}$ protein levels. Data are expressed as arbitrary units (average of five independent experiments; $P<0.05 ; *$ versus $\mathrm{C}$ ). Lamin B1 was used as loading control. Corilagin inhibits the interaction between $\mathrm{NF} \kappa \mathrm{B}$ and oligonucleotides mimicking $\mathrm{NF} \kappa \mathrm{B}$ binding sites (panel (b) $\mathrm{NF} \kappa \mathrm{B}$ consensus sequence A; panel (c) NF $\kappa$ B consensus sequence B). EMSA analysis was performed on binding reactions conducted in the presence of the indicated $\mathrm{nM}$ concentrations of corilagin.

and $\mathrm{NF} \kappa \mathrm{B}$ activation and that corilagin, thanks to its anti-inflammatory and free radical scavenging characteristics, prevents CS induced cell damage.

\section{Conflict of Interests}

The authors declare that there is no conflict of interests. 


\section{Acknowledgment}

This work was supported by a contribution from Chiesi Foundation, 2011, to Monica Borgatti.

\section{References}

[1] B. J. Ingebrethsen, "Aerosol studies of cigarette smoke," Recent Advances in Tobacco Science, vol. 12, pp. 54-142, 1986.

[2] W. A. Pryor, D. G. Prier, and D. F. Church, "Electron-spin resonance study of mainstream and sidestream cigarette smoke: nature of the free radicals in gas-phase smoke and in cigarette tar," Environmental Health Perspectives, vol. 47, pp. 345-355, 1983.

[3] B. Messner and D. Bernhard, "Smoking and cardiovascular disease: mechanisms of endothelial dysfunction and early atherogenesis," Arteriosclerosis, Thrombosis, and Vascular Biology, vol. 34, no. 3, pp. 509-515, 2014.

[4] C. Sticozzi, A. Pecorelli, G. Belmonte, and G. Valacchi, "Cigarette smoke affects ABCAl expression via liver X receptor nuclear translocation in human keratinocytes," International Journal of Molecular Sciences, vol. 11, no. 9, pp. 3375-3386, 2010.

[5] K. Kunchithapautham, C. Atkinson, and B. Rohrer, "Smoke exposure causes endoplasmic reticulum stress and lipid accumulation in retinal pigment epithelium through oxidative stress and complement activation," Journal of Biological Chemistry, vol. 289, no. 21, pp. 14534-14546, 2014.

[6] W. H. Evans and P. E. M. Martin, "Gap junctions: structure and function," Molecular Membrane Biology, vol. 19, no. 2, pp. 121136, 2002.

[7] R. P. Rainey, I. G. Gillman, X. Shi et al., "Fluorescent detection of lipid peroxidation derived protein adducts upon in-vitro cigarette smoke exposure," Toxicology Mechanisms and Methods, vol. 19, no. 6-7, pp. 401-409, 2009.

[8] K. Avezov, A. Z. Reznick, and D. Aizenbud, "Oxidative damage in keratinocytes exposed to cigarette smoke and aldehydes," Toxicology in Vitro, vol. 28, no. 4, pp. 485-491, 2014.

[9] H. Xue, K. Sun, W. Xie et al., "Etanercept attenuates short-term cigarette-smoke-exposure-induced pulmonary arterial remodelling in rats by suppressing the activation of TNF- $\alpha / \mathrm{NF}-\kappa \mathrm{B}$ signal and the activities of MMP-2 and MMP-9," Pulmonary Pharmacology and Therapeutics, vol. 25, no. 3, pp. 208-215, 2012.

[10] I. H. Heijink, S. M. Brandenburg, J. A. Noordhoek, D. S. Postma, D.-J. Slebos, and A. J. M. van Oosterhout, "Characterisation of cell adhesion in airway epithelial cell types using electric cellsubstrate impedance sensing," European Respiratory Journal, vol. 35, no. 4, pp. 894-903, 2010.

[11] K. Husgafvel-Pursiainen, "Genotoxicity of environmental tobacco smoke: a review," Mutation Research/Reviews in Mutation Research, vol. 567, no. 2-3, pp. 427-445, 2004.

[12] D. B. Alexander and G. S. Goldberg, "Transfer of biologically important molecules between cells through gap junction channels," Current Medicinal Chemistry, vol. 10, no. 19, pp. 20452058, 2003.

[13] D. A. Goodenough, J. A. Goliger, and D. L. Paul, "Connexins, connexons, and intercellular communication," Annual Review of Biochemistry, vol. 65, pp. 475-502, 1996.

[14] H. A. Dbouk, R. M. Mroue, M. E. El-Sabban, and R. S. Talhouk, "Connexins: a myriad of functions extending beyond assembly of gap junction channels," Cell Communication and Signaling, vol. 7, article 4, 2009.
[15] M. Vinken, E. Decrock, L. Leybaert et al., "Non-channel functions of connexins in cell growth and cell death," Biochimica et Biophysica Acta, vol. 1818, no. 8, pp. 2002-2008, 2012.

[16] T. Kojima, M. Murata, M. Go, D. C. Spray, and N. Sawada, "Connexins induce and maintain tight junctions in epithelial cells," Journal of Membrane Biology, vol. 217, no. 1-3, pp. 13-19, 2007.

[17] C. Luchese, E. C. Stangherlin, B. M. Gay, and C. W. Nogueira, "Antioxidant effect of diphenyl diselenide on oxidative damage induced by smoke in rats: involvement of glutathione," Ecotoxicology and Environmental Safety, vol. 72, no. 1, pp. 248-254, 2009.

[18] N. Holzer, K. F. Braun, S. Ehnert et al., "Green tea protects human osteoblasts from cigarette smoke-induced injury: possible clinical implication," Langenbeck's Archives of Surgery, vol. 397, no. 3, pp. 467-474, 2012.

[19] J. A. D. S. Jaques, P. H. Doleski, L. G. Castilhos et al., "Free and nanoencapsulated curcumin prevents cigarette smoke-induced cognitive impairment and redox imbalance," Neurobiology of Learning and Memory, vol. 100, pp. 98-107, 2013.

[20] C. Sticozzi, G. Belmonte, F. Cervellati et al., "Resveratrol protects SR-B1 levels in keratinocytes exposed to cigarette smoke," Free Radical Biology and Medicine, vol. 69, pp. 50-57, 2014.

[21] Y. Sudjaroen, W. E. Hull, G. Erben et al., "Isolation and characterization of ellagitannins as the major polyphenolic components of Longan (Dimocarpus longan Lour) seeds," Phytochemistry, vol. 77, pp. 226-237, 2012.

[22] S. Okabe, M. Suganuma, Y. Imayoshi, S. Taniguchi, T. Yoshida, and H. Fujiki, "New TNF- $\alpha$ releasing inhibitors, geraniin and corilagin, in leaves of acer nikoense, megusurino-ki," Biological and Pharmaceutical Bulletin, vol. 24, no. 10, pp. 1145-1148, 2001.

[23] W. G. Duan, Z. Q. Shen, M. Yan, Y. Yun, and L. Y. Zhang, "Corilagin, a promising natural product to treat cardiovascular diseases," in Phytopharmacology and Therapeutic Values II, J. N. Govil, V. K. Singh, and S. K. Mishra, Eds., pp. 163-172, 2008.

[24] D. K.-P. Hau, G.-Y. Zhu, A. K.-M. Leung et al., "In vivo anti-tumour activity of corilagin on Hep3B hepatocellular carcinoma," Phytomedicine, vol. 18, no. 1, pp. 11-15, 2010.

[25] L. Zhao, S.-L. Zhang, J.-Y. Tao et al., "Preliminary exploration on anti-inflammatory mechanism of Corilagin (beta-1O-galloyl-3,6-(R)-hexahydroxydiphenoyl-d-glucose) in vitro," International Immunopharmacology, vol. 8, no. 7, pp. 1059-1064, 2008.

[26] R. Gambari, M. Borgatti, I. Lampronti et al., "Corilagin is a potent inhibitor of NF-kappaB activity and downregulates TNF-alpha induced expression of IL-8 gene in cystic fibrosis IB3-1 cells," International Immunopharmacology, vol. 13, no. 3, pp. 308-315, 2012.

[27] S. Kinoshita, Y. Inoue, S. Nakama, T. Ichiba, and Y. Aniya, "Antioxidant and hepatoprotective actions of medicinal herb, Terminalia catappa L. from Okinawa Island and its tannin corilagin," Phytomedicine, vol. 14, no. 11, pp. 755-762, 2007.

[28] Y. Zhu, A. Chidekel, and T. H. Shaffer, "Cultured human airway epithelial cells (Calu-3): a model of human respiratory function, structure, and inflammatory responses," Critical Care Research and Practice, vol. 2010, Article ID 394578, 8 pages, 2010.

[29] G. Valacchi, P. A. Davis, E. M. Khan et al., "Cigarette smoke exposure causes changes in Scavenger Receptor B1 level and distribution in lung cells," The International Journal of Biochemistry \& Cell Biology, vol. 43, no. 7, pp. 1065-1070, 2011.

[30] M. Borgatti, L. Breda, R. Cortesi et al., "Cationic liposomes as delivery systems for double-stranded PNA-DNA chimeras 
exhibiting decoy activity against NF- $\kappa$ B transcription factors," Biochemical Pharmacology, vol. 64, no. 4, pp. 609-616, 2002.

[31] M. Borgatti, I. Lampronti, A. Romanelli et al., "Transcription factor decoy molecules based on a peptide nucleic acid (PNA)DNA chimera mimicking Spl binding sites," Journal of Biological Chemistry, vol. 278, no. 9, pp. 7500-7509, 2003.

[32] S. Galardi, N. Mercatelli, M. G. Farace, and S. A. Ciafrè, "NF$\kappa \mathrm{kB}$ and c-Jun induce the expression of the oncogenic miR221 and miR-222 in prostate carcinoma and glioblastoma cells," Nucleic Acids Research, vol. 39, no. 9, pp. 3892-3902, 2011.

[33] G. Gao and S. C. Dudley Jr., "Redox regulation, NF- $\kappa$ B, and atrial fibrillation," Antioxidants and Redox Signaling, vol. 11, no. 9, pp. 2265-2277, 2009.

[34] A. van der Vliet and C. E. Cross, "Innate antioxidant defense systems in the respiratory tract," BioFactors, vol. 15, no. 2-4, pp. 83-86, 2001.

[35] S. Prasad, C. M. Hogaboam, and G. Jarai, "Deficient repair response of IPF fibroblasts in a co-culture model of epithelial injury and repair," Fibrogenesis and Tissue Repair, vol. 7, no. 1, article 7, 2014.

[36] R. Castagna, P. A. Davis, V. T. Vasu et al., "Nitroxide radical TEMPO reduces ozone-induced chemokine IL-8 production in lung epithelial cells," Toxicology in Vitro, vol. 23, no. 3, pp. 365$370,2009$.

[37] N. D. Magnani, T. Marchini, V. Vanasco, D. R. Tasat, S. Alvarez, and P. Evelson, "Reactive oxygen species produced by NADPH oxidase and mitochondrial dysfunction in lung after an acute exposure to Residual Oil Fly Ashes," Toxicology and Applied Pharmacology, vol. 270, no. 1, pp. 31-38, 2013.

[38] C. Sticozzi, G. Belmonte, A. Pecorelli et al., "Cigarette smoke affects keratinocytes SRB1 expression and localization via $\mathrm{H}_{2} \mathrm{O}_{2}$ production and HNE protein adducts formation," PLOS ONE, vol. 7, no. 3, Article ID e33592, 2012.

[39] K. Aoshiba, M. Koinuma, N. Yokohori, and A. Nagai, "Immunohistochemical evaluation of oxidative stress in murine lungs after cigarette smoke exposure," Inhalation Toxicology, vol. 15, no. 10, pp. 1029-1038, 2003.

[40] B. L. Upham, L. Bláha, P. Babica et al., "Tumor promoting properties of a cigarette smoke prevalent polycyclic aromatic hydrocarbon as indicated by the inhibition of gap junctional intercellular communication via phosphatidylcholine-specific phospholipase C," Cancer Science, vol. 99, no. 4, pp. 696-705, 2008.

[41] S. Ramachandra, L.-H. Xie, S. A. John, S. Subramaniam, and R. Lal, "A novel role for connexin hemichannel in oxidative stress and smoking-induced cell injury," PLoS ONE, vol. 2, no. 8, article e712, 2007.

[42] H. Hennemann, T. Suchyna, H. Lichtenberg-Fraté et al., "Molecular cloning and functional expression of mouse connexin 40, a second gap junction gene preferentially expressed in lung," The Journal of Cell Biology, vol. 117, no. 6, pp. 1299-1310, 1992.

[43] F. J. Martin and A. S. Prince, "TLR2 regulates gap junction intercellular communication in airway cells," The Journal of Immunology, vol. 180, no. 7, pp. 4986-4993, 2008.

[44] R. van den Berg, G. R. M. M. Haenen, H. van den Berg, and A. Bast, "Transcription factor NF- $\kappa \mathrm{B}$ as a potential biomarker for oxidative stress," British Journal of Nutrition, vol. 86, no. 1, pp. S121-S127, 2001.

[45] S. Rignault, J.-A. Haefliger, B. Waeber, L. Liaudet, and F. Feihl, "Acute inflammation decreases the expression of connexin 40 in mouse lung," Shock, vol. 28, no. 1, pp. 78-85, 2007.
[46] E. Oviedo-Orta, B. R. Kwak, and W. Howard Evans, Connexin Cell Communication Channels: Roles in the Immune System and Immunopathology, CRC Press, 2013.

[47] M. Koval, M. Billaud, A. C. Straub et al., "Spontaneous lung dysfunction and fibrosis in mice lacking connexin 40 and endothelial cell connexin 43," The American Journal of Pathology, vol. 178, no. 6, pp. 2536-2546, 2011.

[48] Z. Wang, Q.-Y. Guo, X.-J. Zhang et al., "Corilagin attenuates aerosol bleomycin-induced experimental lung injury," International Journal of Molecular Sciences, vol. 15, no. 6, pp. 9762-9779, 2014.

[49] X.-R. Dong, M. Luo, L. Fan et al., "Corilagin inhibits the double strand break-triggered NF- $\kappa$ B pathway in irradiated microglial cells," International Journal of Molecular Medicine, vol. 25, no. 4, pp. 531-536, 2010.

[50] Y.-J. Guo, L. Zhao, X.-F. Li et al., "Effect of Corilagin on anti-inflammation in HSV-1 encephalitis and HSV-1 infected microglias," European Journal of Pharmacology, vol. 635, no. 1-3, pp. 79-86, 2010. 


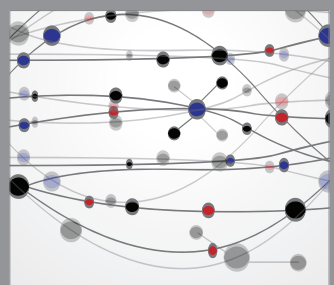

The Scientific World Journal
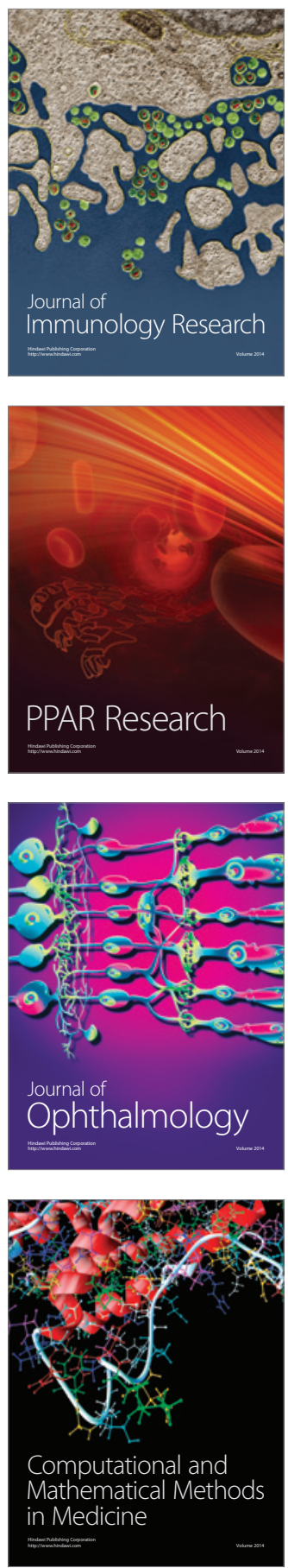

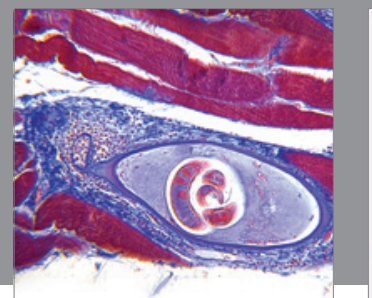

Gastroenterology

Research and Practice
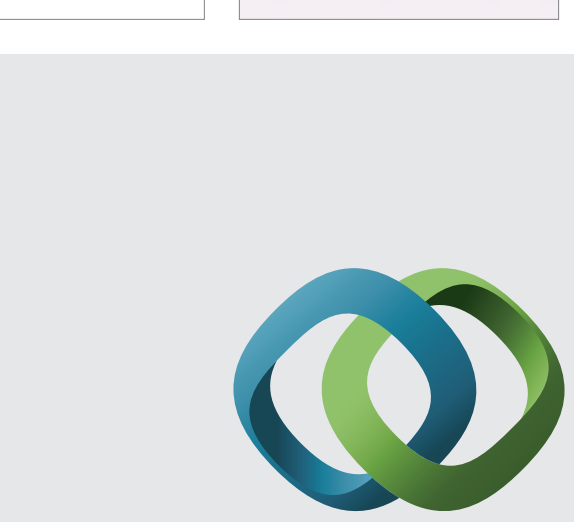

\section{Hindawi}

Submit your manuscripts at

http://www.hindawi.com
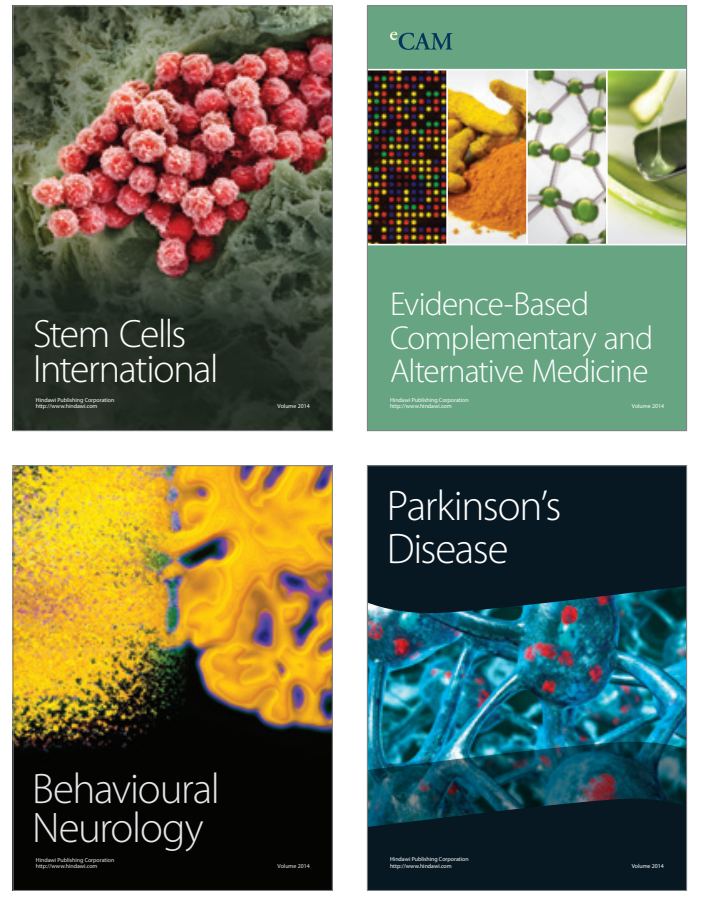
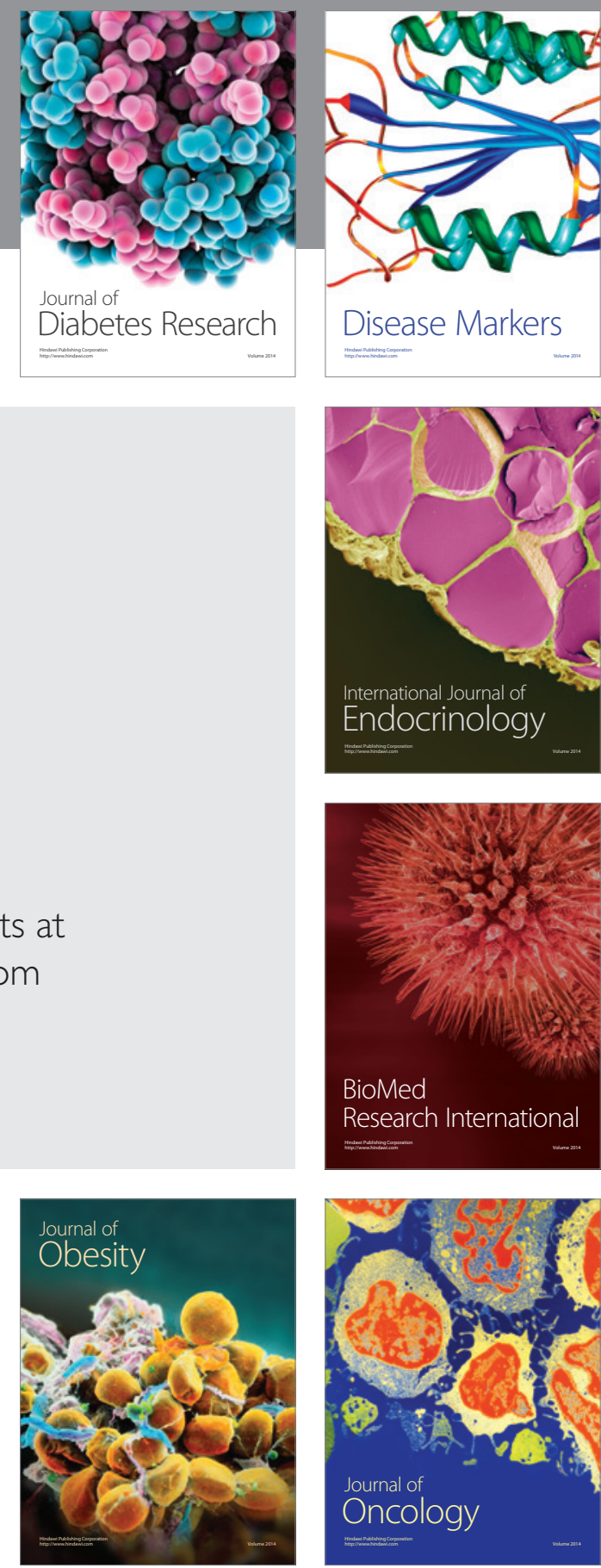

Disease Markers
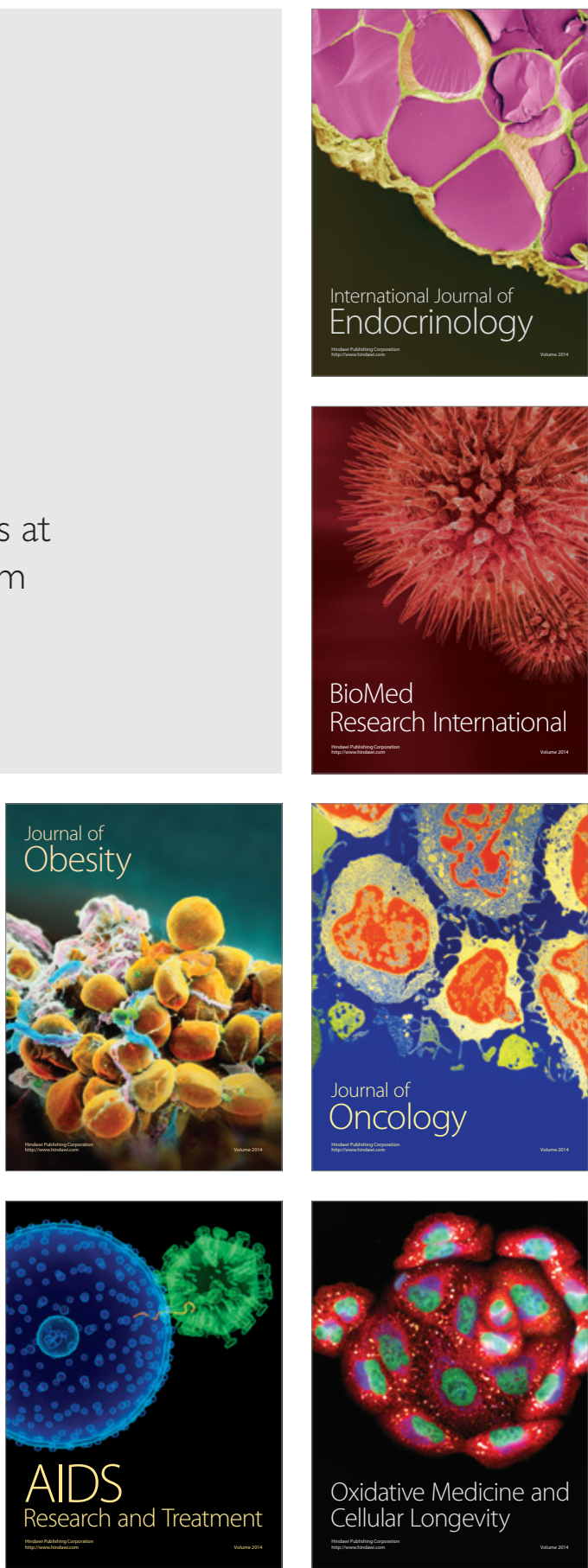